\title{
Um gesto político intersticial e um histórico palimpséstico: a escrita de si em D'est e Là-bas de Chantal Akerman
}

\author{
Roberta Veiga' \\ https://orcid.org/0000-0002-8538-1185 \\ I - UFMG \\ Belo Horizonte (MG), Brasil
}

Resumo: Onde está o histórico e o político quando uma cineasta recusa os procedimentos de rememoração documentais como o arquivo, o testemunho e a encenação, para apenas contemplar espaços de conflito no Leste Europeu de 1993 e em Israel de 2006, sem a eles se imiscuir? Buscando responder tal questão, este artigo produz o argumento de que através da escrita de si - de uma autobiografia instituída nas lacunas da memória sobre o Holocausto - os filmes D'est e Là-bas, de Chantal Akerman, alcançam o político por uma via intersticial - aquela dos afetos e das brechas - e formula uma figura palimpséstica para a história, que não encadeia passado e presente.

Palavras-chave: Chantal Akerman; cinema; política; memória; Holocausto; afetos.

Abstract: An interstitial political gesture and a palimpsestic record: writing per se in D'est and Là-bas - Where are history and politics when a filmmaker refuses procedures of documental recollection such as archives, off-screen narration, and playacting, and instead contemplates spaces of conflict in Eastern Europe 1993 and in Israel 2006 without getting involved in them? In order to answer this question, we argue that, by means of a self-writing style (an autobiography built in the memory gaps of the Holocaust), Chantal Akerman's films D'est and Là-bas reach the political through a crannied route (of affects and cracks) that constructs a palimpsestic picture of history in which past and present are not sequential.

Keywords: Chantal Akerman; cinema; politics; memory; Holocaust; affections.

Leste Europeu, 1993. Israel, 2006. Dois contextos eminentemente históricos e políticos. No início dos anos 90, após a queda do Muro de Berlim, com o fim da Guerra 
Fria e a extinção da União Soviética, o Leste Europeu vivia a transição mais explícita ou direta do sistema socialista para a democracia liberal e capitalista. De 2000 a 2005, a série de conflitos entre israelenses e palestinos na Faixa de Gaza, conhecida como Segunda Intifada, estende-se com os bombardeios do grupo fundamentalista islâmico Hezbollah em várias cidades no território de Israel, em resposta à invasão israelense no Líbano, ocorrida no ano de 1982.

Trata-se aqui do local e da época nos quais têm lugar dois documentários de Chantal Akerman: D'est (versão cinematográfica lançada em maio de 1995)1 e Là-bas (lançado em outubro de 2006). Porém, ao contrário do que se possa esperar, nem um, nem outro, traduz diretamente - no sentido de focar e explicitar - a problemática histórica e política que esses cenários encerram e abrigam. Ao contrário, sonegando toda forma convencional de documentário político, Akerman recusa o enfrentamento claro e incisivo das questões polêmicas e complexas que recobrem, em um, territórios da Rússia, Polônia, Hungria, Tchecoslováquia, ex-Alemanha do Leste, e, em outro, a capital israelense, e se põe a observar Tel Aviv à distância, de dentro de um apartamento, ou a roçar com a câmera povos e paisagens que constituem o lado oriental da Europa.

Là-bas nasce de uma estadia em Tel Aviv, durante a qual Chantal parece ter sido capturada pelos enquadramentos possíveis a partir da janela e pelas sombras do pragueado da persiana do apartamento onde se hospeda e se enclausura. Tal experiência de clausura foi a que restou para reverberar a ideia do produtor Xavier Carniaux, de que ela seria - por seu legado judeu e por sua inquietude mediante a tal condição - a cineasta certa para fazer, àquela altura, um documentário ali. Apesar da resistência inicial em função de sua alegada falta de neutralidade, do temor pela forma como sua história de vida tornava sua visão confusa e a paralisava, o olhar pela janela se fez filme. Là-bas é um dispositivo simples, minimalista². Não vemos Akerman nas ruas da cidade, não vemos o povo local de frente, ela não os encara, como também não confronta ou interpela o conflito entre palestinos e israelenses. Durante praticamente todo o filme, ela está confinada dentro de um apartamento sublocado em Tel Aviv com a câmara dirigida para a janela por onde filma outros prédios, poucas vezes a rua, outras janelas, e pessoas na varanda, das quais não vemos bem o rosto, apenas alguns movimentos. Logo se percebe que a voz que ouvimos em off - a narrar, em primeira pessoa, seu dia a dia e suas lembranças - é da cineasta,

1 "Quando Chantal Akerman recebeu em 1989 uma proposta do Museum of Fine Arts de Boston e da emissora americana de televisão WGBH para criar uma instalação multimídia sobre a união da Comunidade Européia, ela já acalentava de longa data uma ideia de fazer um filme sobre a Europa Oriental, de onde saíram seus pais (judeus poloneses). Depois de negociações, mudanças e ajustes do projeto inicial, que integrou novos financiadores e parceiros, ela conseguiu viabilizar em 1991 a produção de um longa-metragem rodado em alguns países do leste europeu, intitulado sobriamente $D^{\prime} E s t$ (Do Leste) e finalizado em 1993. Bem recebido no circuito cinematográfico, o filme voltou a circular numa das salas da instalação 'D'Est, au bord de la fiction', a primeira da carreira de Akerman, que itinerou por vários países (EUA, França, Bélgica, Espanha e Alemanha) em 1995-6" (ARAúJO, 1993)

2 Para uma discussão detalhada acerca do dispositivo da janela em Là-bas, sua relação de mise-en-abyme e a captura distanciada das pessoas nas janelas dos prédios de frente ao apartamento de Chantal, como miniaturas (conferir VEIGA, 2010). 
que filma, e da personagem, que ali está, habitando aquele exíguo espaço, do qual, além da janela que dá para o fora, vemos muito pouco: o abajur, uma mesa de centro, uma cadeira, as persianas, parte da sala. Se ouvimos sua voz off a comentar pequenas ocorrências do dia a dia e a relatar suas memórias, do olhar que ela constrói com a câmera vemos pouco; ela mesmo não vemos. Chantal aparece raras vezes de modo fugaz e opaco.
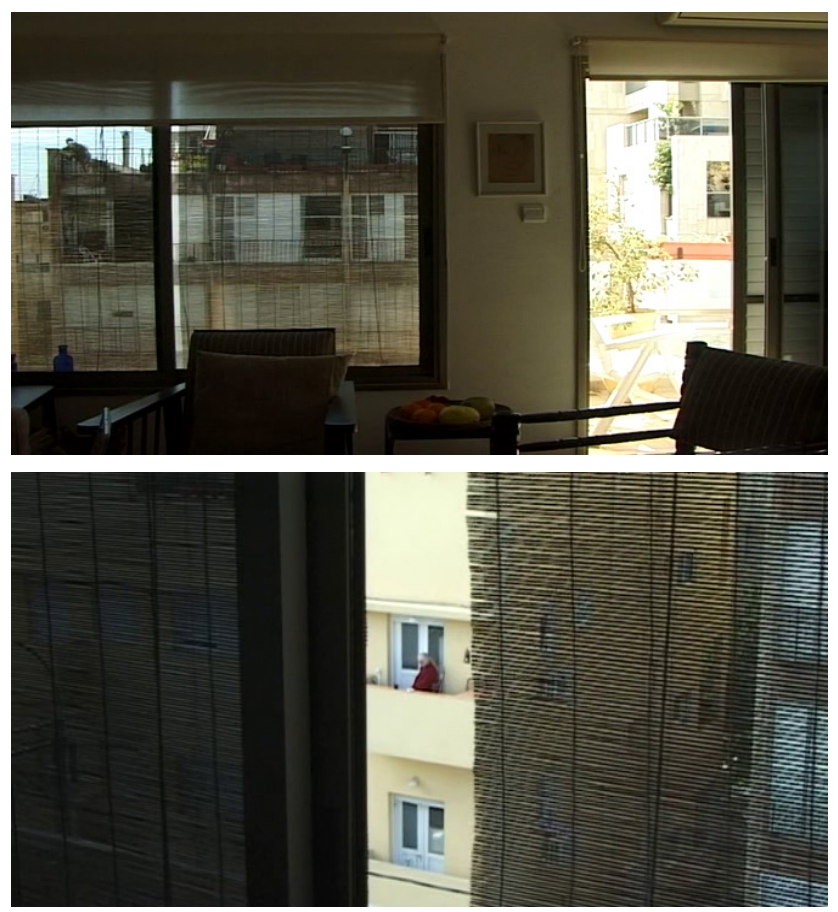

Fig. 1. Là-bas: câmara dirigida a janela capta parte do apartamento e as janelas com as persianas.

Fig. 2. Là-bas: miniaturas surgem entrecortadas, reenquadradas, por outros retângulos interiores à moldura da janela.

Ainda que, nas palavras da diretora, houvesse "razões evidentes, históricas, sociais e políticas, que motivam tantos documentários ou reportagens", elas "muito raramente compartilham um olhar atento e calmo", portanto, em D’est, Akerman é impulsionada por um sentimento de familiaridade: "Queria filmar lá, ao meu modo documental, roçando a ficção. Tudo o que me toca (...). Eu queria registrar os sons dessa terra, tornar sensível a paisagem ao passar de uma língua a outra, com suas diferenças e similitudes" (AKERMAN, 2010, p. 62).

Akerman não afirma diretamente uma motivação política, mas afetiva, em razão de sua história com o Leste Europeu. O olhar da cineasta percorre a cidade, as estações, os campos, as ruas, adentra os espaços domésticos e públicos, aproxima-se dos rostos, porém nega qualquer relação histórica dada, qualquer contextualização, ou narrativa, que linearize passado-presente. Não há uma procura ostensiva por sinais do capitalismo nas cidades ou qualquer testemunho que esclareça a transição econômica, nem mesmo sinais 
do passado remoto da Segunda Guerra. Ela não enquadra símbolos do judaísmo, nem nada que, a princípio, evoque simbolicamente a lembrança do holocausto, seja da história oficial ou da história dos vencidos. Do ponto de vista formal, o filme não abarca em suas estratégias o uso do off, como meio de explicar ou comentar, e também não faz uso de arquivos, obstruindo qualquer contraposição que a montagem poderia construir entre fotogramas do passado - seja ele dos campos de concentração na Polônia ou do socialismo na Rússia - que oponha de forma muito fácil passado e presente. Enfim, não é desse modo, comum ao documentário em seus procedimentos de rememoração ou denúncia - uso de arquivos, testemunho e formas de reencenação - que as imagens da memória irão sobreviver, ameaçadas que estão pela mercadoria, o consumo e o tempo apressado do capital que rouba os empregos dos cidadãos e inflaciona a economia dos poucos eleitos. Tais procedimentos serão descartados em prol de uma aposta na pura presença da câmara no espaço habitado - seja ele público ou doméstico - a se mover lenta e constantemente; e na duração do olhar para o cotidiano, os habitus, as paisagens. O testemunho precisará se dar de outra forma. $\mathrm{O}$ arquivo, no que ele concerne ao passado, um registro do já vivido, só pode se insinuar iconograficamente pelas imagens do presente, como traços que sulcam o mapa e borram a paisagem.
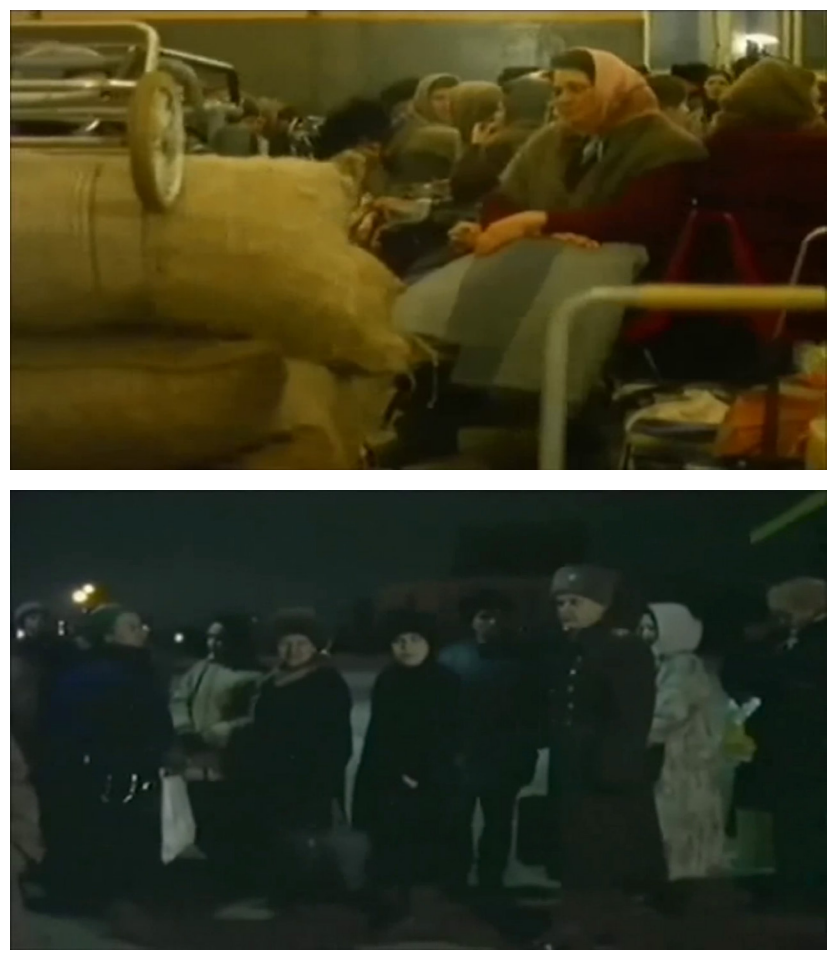

Fig. 3. D'est: ambiente interno público, estação de trem. Fig. 4. D'est: ambiente externo (Polônia), fila de espera do trem. 


\section{Por uma leitura política intersticial do dispositivo autobiográfico}

Duas motivações, a princípio completamente separadas, dois embates geopolíticos (religiosos e econômicos) específicos, porém próximos pela mesma experiência pessoal, a da realizadora, que, se não os explica diretamente, nos permite acossar a questão que aqui nos interessa. Em ambos documentários, a postura de Akerman parece ser da recusa da política e da história no palco de grandes acontecimentos políticos e históricos. Há quem critique fortemente os filmes pela falta de uma abordagem direta dos eventos naqueles contextos, e afirme que, ao se posicionar num fora, sem se envolver, a cineasta adota posição de neutralidade que barra e obstrui qualquer perspectiva política que poderia se instituir nos dispositivos construídos. Mas, seria, de fato, possível uma proteção contra a história ou uma abstenção política, quando, na experiência pessoal e afetiva dessa realizadora, as histórias dos povos, das guerras e das revoluções em jogo, se atravessam e se conjugam? Seria possível Akerman não se envolver ali, quando é na história de sua vida, na descoberta tardia, nebulosa e nunca inteira de suas raízes judias, de sua relação com Holocausto e de seu pertencimento hereditário aos hábitos do Leste Europeu que esses dois mundos políticos se cruzam? Chantal é filha de judeus que habitavam a Polônia e que durante a Segunda Guerra foram levados para o campo de concentração em Auschwitz. Tanto a experiência da vida na Polônia quanto as agruras do Holocausto foram vividas por ela indiretamente, como uma história lacunar, despedaçada, interditada nas reuniões familiares e subsumida no discurso dos pais.

A descendência judia com tudo o que ela poderia significar atravessa Chantal como uma poderosa pós-memória que forma a sua própria. Com essa pós-memória, o não vivido, o não dito, o não elaborado, esburaca sua própria história que não pode se constituir sem ela. Não por acaso, enquanto cineasta, sua obra é sempre um colocar-se em obra, ou seja, colocar em processo sua própria subjetividade, em que buracos não são tapados, mas vividos, principalmente na complexidade e intensidade de sua relação com a mãe, que é constitutiva de sua filmografia em alguns momentos de forma bem evidente (como em News From Home, de 1977; e Rendevouz d'Anna, de 1978, e em outros de modo mais sútil, como Jeanne Dielman, 23, Quai du Commerce, 1080 Bruxelles, de 1975; e Toute une Nuit, de 1982).

Dito isso, interpela-nos então uma dimensão histórica que não aparece circunscrita a um contexto ou a um pano de fundo, tampouco claramente explicitada na vida de Chantal Akerman e seus pais, mas que se imiscui nos afetos que os filmes sensivelmente convocam, bem como nos mecanismos de si que a cineasta faz operar.

Nossa tentativa aqui é inverter o jogo que situa o que é político e histórico nessas obras no pano de fundo ou na temática (que parecem demandar uma abordagem documental strictu sensu), ou em uma cinematografia ativista que implicaria na participação efetiva do corpo da cineasta na cena dos conflitos, para dizer de uma experiência autobiográfica, 
portanto memorial, do cinema que, ao se abrir para o que é próprio do ensaio, e do experimentalismo que ele abarca em sua natureza errática, subjetiva e impressionista, gera uma estética que faz brotar, não sem dificuldades, o político ${ }^{3}$. É esse cinema de experiência de si, no qual a história do sujeito está sempre em construção pelo cinema, que nos permite, ao perscrutar a obra de Akerman, perceber a aproximação entre esses dois mundos (do Leste Europeu e de Israel, de conflitos e convulsões) não como um a priori histórico, mas como mundos criados: o de D'est e o de Là-bas a partir não só da inserção da cineasta no presente de certos acontecimentos, mas de sua memória e do impulso estético e criativo que essa memória traz. Na verdade, a aposta é de que se trata menos de um modo de captura, de abordagem ou de registro da cena política do que de uma experiência com o espaço que já é, ela mesma, uma experiência de si carregada de mediações afetivas e perceptivas que o olhar para aqueles mundos nos mostra. Dessa maneira, a política não está lá no mundo filmado e também não está na crença do cineasta que a imputa ao mundo; ela nasce intersticialmente quando o encontro já é atravessado por uma memória. A história só pode ser encampada, portanto, no que ela tem de avesso ao historicismo.

Mas é o preço a se pagar pela "revolução copérnica" da história: levar em conta os processos da memória, logo, do inconsciente e da imagem, obriga a um deslocamento radical da razão na história hegeliana. Não é mais o fio do Espírito absoluto, mas às mechas desfiadas de imagens muito relativas que se constrói e se desconstrói a historicidade. Não é mais em nome da eterna presença da Ideia, mas em nome de frágeis sobrevivências - psíquicas ou imateriais - que o passado deve ser 'atual'. Não é mais o universal que se realiza no particular, mas o particular que, sem síntese definitiva, dissemina-se por toda parte (DIDIHUBERMAN, 2015, p. 130).

Tampouco assistimos a um documentário ativista no qual a cineasta participa de acontecimentos e manifestações de ordem política. O que temos diante de nós é uma forma histórica que só pode se dar num lampejo do gesto pessoal, instituída na forma fílmica, nas estratégias formais e expressivas escolhidas e na natureza processual (de se colocar em obra) própria ao conjunto da obra da autora; características essas que concedem uma marca autoral ao cinema de Akerman. Em função da experiência da pós-memória, da dificuldade de se constituir historicamente, da inevitabilidade de ter no cinema

3 Por isso, é preciso notar que o autobiográfico aqui, de Akerman, se afasta completamente da produção documental de gênero biográfico, portanto não se define com essa noção um gênero, um conjunto de opções de linguagem, uma gramática, mas uma função que o filme aciona e que é fundamental para trazer a dimensão da memória, da experiência subjetiva e de um mecanismo fílmico que se interligam. As estratégias formais convencionais dos documentários biográficos acionam o passado em forma de uma disposição clara das lembranças como testemunhos do vivido. Entrevistas, material de arquivo e narração em off situam o passado, contextualizando acontecimentos e esclarecendo conjuntura. O uso da narrativa cronológica e linear que conta uma história de vida é lugar de conforto para o espectador. Nada disso está no cinema de Akerman. A experiência do espectador é de um pathos pela travessia da duração das imagens e do filme, a imersão corporal em uma experiência sensível que desloca modos de ver e dificulta sínteses simbólicas. 
um modo de se colocar em obra, mas sabê-lo e vivê-lo como sempre falho e incompleto, que a política e a história só podem se dar como restos, vestígios, de par em par com a noção mesma de memória.

O tecido do tempo é fundamentalmente lacunar e a continuidade temporal não deve ser entendida como um dado, mas como uma obra, uma construção do sujeito, diante sobretudo da angústia que significa para ele o ato de reviver o desaparecido (e, portanto, o descontínuo), de enfrentar a morte (BRANCO, 1990, p. 41).

Arriscamos, portanto, o esboço de duas hipóteses para entender de que modo esses filmes juntos e separados, se fazem históricos e políticos. E, nesse sentido, perguntamo-nos que formas políticas e históricas seriam essas que os filmes cifram em seus dispositivos? As hipóteses seriam: 1) a forma política se dá de um modo intersticial próprio ao mecanismo de si que o filme engendra, portanto, na maneira como o autobiográfico ocorre; 2) a forma histórica se assenta no cotidiano que, como potencializador da complexidade temporal, rejeita a sucessão passado-presente e opera uma não-separação de ambos, portanto, uma forma histórica correlata à mnemônica. Ambos os eixos, logicamente, valem para os dois filmes, porém se modulam de forma diferente em cada um, tanto no mecanismo quanto na escritura fílmica.

Se tanto em Là-bas quanto em D'est uma escrita de si está em processo, é possível dizer que no primeiro o caráter autobiográfico é adotado de saída, é direto, enquanto no segundo trata-se de uma autobiografia indireta, transversal. Se ambos operam com essa memória esfiapada como constituinte do presente contínuo do cotidiano, em Là-bas, a a-historicidade se assenta no dispositivo de confinamento que cria uma condição fantasmática, enquanto em D'est, ela está na forma de um palimpsesto que o mapeamento dos territórios pela câmara lenta e deslizante engendra.

Tanto em D'est quanto em Là-Bas, a cineasta se instala no cotidiano ${ }^{4}$ - num presente contínuo - que, como um fio terra, uma temporalidade una, só pode evocar o passado como sombra, um fora de campo (espacial e temporal) a se insinuar e tensionar as imagens, portanto um entre-imagens. Nessa força cotidiana, nessa diariedade, a memória é menos elaboração do que afetação pela imagem - pregnância do olhar que a duração, a lentidão, o formalismo rigoroso dos enquadramentos e movimentos de câmera alcançam em sua obra. Em Maurice Blanchot (2007, p.237), o cotidiano tem esse traço essencial de não se deixar apanhar. Ele escapa, porque "pertence à insignificância, e o insignificante é sem verdade, sem realidade, sem segredo, mas é talvez também o lugar de toda significação possível". Ao mesmo tempo inesgotável e inacabado, o cotidiano é, para Blanchot (2007, p. 236), fastidioso, penoso. É porque, como diz o autor, "o cotidiano não é uma existência média, estatisticamente constatável, de uma sociedade dada num momento dado" que ele guarda essa potência temporal que mencionamos. Seguindo nessa toada, fica fácil

4 Inclusive trata-se de uma constante nas obras de Chantal Akerman. Conferir Margulies, Ivone (2016). 
perceber que, ao se fazer da matéria ordinária do cotidiano, onde nada acontece, a força do cinema de Akerman está mesmo na experiência perceptiva, sensorial, do espectador que precisa acionar outras relações com a imagem que não a dos sentidos linearmente, sequencialmente e literalmente construídos pelas narrativas informativas, argumentativas ou ficcionais, mas a do sentido epitelial, visceral, que se depreende do atrito com as imagens e da escolha do que cortar - o fora de campo - e do que montar, como associar cenas, cenas e texto, montagem.

\section{Là-bas e a pós-memória: o fantasmático da história}

Podemos dizer que em Là-bas estamos presos com a cineasta/personagem/narradora em um cotidiano de dentro, da vida enclausurada no apartamento em TelAviv, e que em D'est somos lançados ao cotidiano de fora através dos travellings lentos e longos, dos enquadramentos fixos, nos espaços das cidades do Leste Europeu. Instalar-se nessa duração do anódino poderia parecer recusa do passado - e com ela tudo que faz história - em prol do tempo presente. Mas não se trata disso. Nessa superfície escorregadia, o passado ainda sobrevive, é aquilo que resta, o traço que só pode ser entrevisto em alguma brecha ou projeção, escapando de uma temporalidade linear do antes-agora-depois. Afeita ao tecido mnemônico, assim como em Marcel Proust ${ }^{5}$, a história é feita do esquecido ou até mesmo do não vivido e, por isso, de invenção. O passado não está localizado ou datado, mas vai constituir a experiência fílmica como matéria de percepção, como conformadora de uma ação: a do ver. Donde o pathos político, se assim podemos dizer, não é uma experiência narrativa, conteudista, mas uma experiência sensível encarnada no corpo que vê. Não se trata, portanto, de, nesses filmes, conhecer a fratura histórica do dano irreparável do Holocausto ou da transição de sistemas econômicos que destituem formas de vida, mas de senti-la na presença muda que é o passado: seja nas lembranças contadas pela narradora em Là-bas - a mesma Chantal -, que emergem fragmentadas e poeticamente como numa confissão; seja pelo roçar da câmara na pele das paisagens e rostos humanos, que guardam traços que, ao sulcarem a imagem, são camadas, extratos de experiências únicas que se adensam no habitus de um lugar, o Leste Europeu, e de uma história de vida contada em Tel Aviv. Daí a dimensão intersticial e palimpséstica.

Em Là-bas, esse passado que não se apresenta diretamente na imagem, essa história coletiva que não se inscreve materialmente, surge pela via autobiográfica do filme. Chantal encarna o passado que não a assombra, mas faz dela uma sombra, faz dela um fantasma agindo no filme. Para Greg Youmans, no artigo Ghosted Documentary: Chantal Akerman's Là-Bas (2009), no assombro (o haunted), é a memória do passado que vem perseguir personagens e cineastas, uma vez que o assombro é o tormento do passado que ocorre no presente. Aqui, trata-se de uma dimensão fantasmática do presente (o ghosted),

5 Para Walter Benjamin, em Marcel Proust, o importante não é o que ele viveu, mas o que rememora e, nesse trabalho de rememoração, "a recordação é a trama e o esquecimento a urdidura" (BENJAMIN, 1994, p.37). 
que já foi sugado pelo assombro, fazendo do sujeito ele próprio um fantasma. Caso Là-Bas fosse uma assombração, o espectador viveria o passado também como assombro; experimentaríamos uma carga afetiva através da erupção de figuras e impressões do passado no presente. Porém, o que se dá no ghosted é o contrário: é o escoamento da conexão afetiva e interpessoal com o cotidiano pelo peso de um evento político e histórico não resolvido ou talvez insolúvel. Ou seja, o trauma do Holocausto por ela herdado não surge como a assombração que vai se resolver no presente, mas permanece inscrito nela como parte do presente que entra numa condição fantasmática. Como fantasma, ela não se comunica com os vivos. Confinada no apartamento, ela vaga sem aparecer diretamente, mas apenas em vultos, sombras, barulhos e na voz que ao mesmo tempo lhe fixa na rotina vivida - como notas em um diário. É atravessada, ainda, por histórias fragmentadas e ligações pouco claras com a família judia, o pai, o avô, a tia que se suicidou. Entre passado e presente, é como se ela habitasse um não lugar. Tal condição fantasmática, dada a ver pelo confinamento, frente a uma paisagem contemporânea tão politicamente carregada, como a de Israel, instala no vazio do afeto algo pungente e doloroso.

Trata-se do grão do trauma vivido por uma geração que sofreu indiretamente o Holocausto e que não conseguiu produzir uma comunicação desse acontecimento histórico de forma a lidar com ele; que não conseguiu trazer a memória (porque turva e esfiapada, indireta) para o presente de forma a reconciliá-la. Daí que, em Là-Bas, esse acontecimento medonho não é mais que uma assombração. Incorporado, misturou o passado e o presente vivido, tornando a vida fantasmática. Essa condição fantasma que está impregnada na secura e severidade do filme, na recusa de sair do apartamento e de viver algo que não se deu, é que parece emperrar a dimensão política mais direta no filme. Porém, há de se falar de um revés político que é bem mais intersticial que explícito. Parece haver aqui um princípio paradoxal: a incomunicabilidade do fantasma e a comunicabilidade do cinema, a partilha pela estética. Se pensarmos que, para Jacques Rancière, a política "se define pela partilha do sensível que se refere tanto ao que é comum, quanto ao que é diferente, determinando as inclusões e exclusões nos lugares" (VEIGA, 2015a, p.196), aqui tudo se passa como se só fosse possível partilhar a incomunicabilidade, no limite, partilhar a impossibilidade da partilha, quando o político não é mais possível.

Se essa condição fantasmática de Chantal é pura incomunicabilidade com aqueles que vemos pela janela, é porque o mecanismo do filme projeta outras incomunicabilidades: aquela com os judeus cuja descendência ela não pode explicar, aquela com os mortos da Guerra, e com seus pais, para os quais a experiência dos campos tornou-se um interdito. Há, portanto, uma partilha da condição fantasmática com aqueles que no presente vivem a condição da guerra histórica entre israelenses e palestinos, pois também vivem a sombra dessa situação carregada no passado. 
Eu pensava na minha tia Ruth quando ela voltou do convento, após a guerra, parece que ela mudou, que antes ela era cheia de vida... Ela me amedrontava... Se meu avô é um descendente do rabino de Belz, então eu também sou. Tento perceber em mim se posso senti-lo. Sim, sim, eu o sinto. Não agora, não sinto mais. Me dou conta de que conheço mais palavras em hebraico do que eu pensava... Se eu tivesse nascido aqui, minha mãe teria me deixado brincar na rua com outras crianças... E se tivéssemos ido para Israel no lugar da Bélgica? (extrato do filme Là-bas)

O modo político intersticial - como um fluído que sobrevive na pele se esgueirando por entre as membranas - só poderia se manifestar no corpo, através da experiência do espectador que é submetido à secura, ao nada acontece, às disjunções mnemônicas da voz off, à impossibilidade de viver o dia a dia manifesta no próprio dia a dia, à reprodução mecânica do ato de ver. Se o dispositivo institui essa condição fantasmática, é porque arrasta o espectador para essa experiência pessoal: da incomunicabilidade do trauma. Preso no espaço/tempo contínuo do cotidiano, o filme rejeita a fantasia libertadora do assombrado, qualquer possibilidade de perdão ou cura pela comunicação com o outro e até com o próprio passado, que já virou corpo. Talvez uma boa formulação seja que a recusa em falar do conflito palestina-israelense, de encontrar os judeus e de eles saberem algo de fora, enfim, que a opção pela clausura como única possibilidade para que haja filme, diga, sobretudo, da impossibilidade da partilha nesse cenário de guerra do qual Tel Aviv é palco; diga ainda de um mundo sem espaço, para que o passado se reconcilie no presente. O trauma do passado produz fantasmas em vida: a frustração de que Israel não é o paraíso.

Ao não sair pelas ruas de Tel Aviv, ao sonegar esse ato político do documentarista, do encontro com outro (como defende Jean-Louis Comolli)6, Akerman desvia, mas não anula, o dia a dia conflituoso de uma cidade em estado de guerra. Naquilo que podemos chamar o único momento de acontecimento mesmo do filme, sua voz off conta que, ao sair para comprar cigarros, presenciou a confusão de pessoas após a explosão de uma bomba, próximo ao seu apartamento, que deixara 50 feridos. Esse evento, o dito sobre o aqui e agora da cidade, ressignifica o filme, fazendo ricochetear presente e passado. Se em todo o filme o confinamento (das lembranças e da rotina) e o fora (do outro lado da janela, a cidade) parecem não se ligar, aqui uma liga tácita se faz. O confinamento foi invadido por um fora-de-campo não mais concernente às bordas do quadro,

6 Ao dizer da potência do documentário em relação ao espetáculo, Jean-Louis Comolli ressalta com muita ênfase o caráter de encontro com o outro no documentário, do qual o sujeito filmado participa do dispositivo em sua constituição, portanto, não apenas está ali para a lente, mas entra numa negociação na qual também se apodera do filme. "Filmar aqueles que se dispõem a isso, que se entregam por meio de um dispositivo que eles propõem e pelo qual eles seriam também - ou primordialmente - responsáveis" (COMOLLI, 2008, p.54). Nessa medida, Chantal Akerman se afasta do encontro tal qual formulado aqui, uma vez que aqueles que filmam não sabem que estão sendo filmados (Là-bas) ou só devolvem para câmara o olhar, desconhecendo por quais dispositivos estão sendo capturados. 
do jogo campo-fora (pois esses já estão nas disjunções que o dispositivo do filme opera), mas um fora-de-campo que faz o dispositivo se dobrar, se explicitar e, portanto, se abrir enfim para que o filme cresça. É nesse momento que o gesto político, que sobrevive nos interstícios da escritura fílmica, reverbera. Passado e presente se separam, para novamente se chocarem, e aquelas vidas observadas de longe se coadunam numa mesma experiência de confinamento. Ao olhar da janela e deixar escapar o temor de andar nas ruas da cidade, cristalizada na fantasmagoria que agora se estende na ameaça dos atentados, partilha-se a impossibilidade de se mover, a paralisia daquele que nada pode fazer frente à situação de guerra agora instalada. O olhar que se dirige para fora do apartamento, para aquelas vidas em miniatura, enquadradas da janela, impregna a ambiência do filme dessa dimensão diminuta do viver. Partilha-se o confinamento frente a um estado de exceção, frente à impossibilidade de que a terra prometida produza uma vida em comum.

\section{D'est e o palimpsesto da história: paisagens e rostos}

Se em Là-bas o movimento foi o de ver, por intermédio do autobiográfico, o político e o histórico, em $D^{\prime}$ est partimos do contrário: de ver no coletivo e na paisagem do Leste Europeu uma autobiografia transitiva, indireta, na qual, para Alisa Lebow (2003, p. 47), o rosto do outro substitui o rosto da mãe de Chantal, que substitui o dela própria. A mãe, com sua história de vida e sobrevida ali, é o ponto de partida de Akerman, que a reconhece tanto nos gestos e hábitos que encontra no percurso, quanto nas paisagens naturais e humanas que ecoam. Aqui, novamente, o trauma do passado de um povo:

\section{[...] a predileção pelas estações de embarque e pelas grandes aglomerações gera uma associação quase involuntária com as saídas forçadas, como se, por trás dessa platitude, houvesse um eterno retorno, uma cristalização (camada) simbólica do que já foi vivido que volta em sua inteireza de grão irredutível (RABELO, 2015)ㄱ.}

Essa pós-memória, da geração de filhos dos sobreviventes do Holocausto, é poderosa, porque sua conexão com o objeto (claramente um objeto que falta) não é mediada pela rememoração, mas se dá na projeção. É o olhar de Chantal que imprime nos rostos e paisagens do Leste Europeu o passado vivido por ela através da memória da mãe. O cotidiano filmado forma um palimpsesto a esboçar nesse contínuo, aqui-e-agora dos dias comuns, uma história imprecisa, mais distante - aquela cena primeva das deportações dos judeus para os guetos e campos de extermínio; e o passado mais recente do fim do projeto socialista. Ela parece saber que qualquer busca direta pelo passado é infrutífera, pois vai encontrá-lo já morto, já arquivo, museu, história oficial. Portanto, a memória

7 Texto apresentado, pelo mestrando João Paulo Rabelo, como trabalho final da disciplina Imagem e Mediação, do PPGCOM, da UFMG, em 2015. 
não vai ser encontrada ali, em testemunhos, emblemas, fotos de arquivo. Mas reconhece que as paisagens humanas e naturais são feitas de extratos de tempo, e por isso se deixa percorrê-las.

Não procurarei mostrar a desintegração do sistema nem as dificuldades de entrar em outro, porque quem procura acha, acha muito bem e filtra, assim, sua própria visão com o pré-pensado. Tudo isso aparecerá, sem dúvida, pois não pode ser de outra forma. Mas aparecerá nas entrelinhas. (AKERMAN, 2010, p. 62).

Indireta, a autobiografia de Akerman está entre dois outros e, por isso, de certa maneira, fora dela: entre um passado vivido pela memória da mãe e aquele que se projeta no momento da filmagem pelo rosto dos outros. O olhar dela se faz passagem, um entre-imagens que provoca o político na intensidade dos afetos que se depreendem em mais de duas horas de filme. Para Lebow (2003), não se trata de um filme de volta às raízes, até porque Akerman não procura nenhum ícone judeu, evita narração, evita entrevista - há uma história que na verdade ela ignora e projeta ali. Se as imagens do presente ressoam o passado, é porque a câmera, ela mesma, funciona como uma máquina do tempo, produzindo uma autobiografia ao modo benjaminiano: feita de espaços, momentos e descontinuidades. Entre ela e a mãe, entre o passado e o presente, esse caráter indireto, não específico, não a priori, da procura, surpreende na habilidade de comunicar de forma mais nuançada e sugestiva as ressonâncias entre a história e o presente do que uma aproximação direta.

Para Walter Benjamin (1994, p. 224), é apenas num entre que a verdade - a decifração do passado - emerge: o passado só pode ser pego como uma imagem que lampeja no instante que pode ser reconhecida, e nunca mais de novo. São momentos de transição, fronteiriços. Para o autor, a verdade da história só pode ser encontrada de relance, de passagem, nos intervalos: entre o sono e a vigília, entre o presente e o passado, num momento histórico de transição quando a incerteza do futuro é a única certeza. A verdade não pode ser achada nas estatísticas, nos fatos, nas asserções positivas. A passagem ali é de um sistema econômico para outro, da memória à desmemoria, que o capitalismo representa com seu poder homogeneizante: eis o instante de perigo do qual nos fala Benjamin (1994, p.224): é preciso "apropriar-se de uma reminiscência, tal como ela relampeja no momento de perigo". Ou seja, para Akerman (2010, p. 62), trata-se de filmar o Leste Europeu enquanto ainda há tempo de ver: "Todos aqueles países, em plena mutação, que viveram uma história comum depois da guerra, marcados por essa história até nas entranhas da terra e cujos caminhos, agora, divergem", de ver algo ainda antes do desastre que representa o caos político e econômico do capitalismo.

D'est seria, então, um cinema verités da intersticialidade, pelo qual, ao se olhar por muito tempo os rostos na paisagem e a paisagem nos rostos, a pressão do olhar fixo sozinha

8 O que chamamos aqui de cinema veritè da intersticialidade guardaria a etnografia do cinema-verdade tal qual pensada por Dizga Vertov e Jean Rouch (tanto doméstica, em Là-bas, quanto do Leste Europeu, em D’est), porém provocando a realidade com o uso da câmara sem nela intervir, para que o político surja nas brechas e associações mnemônicas-imagéticas, sem uma construção ficcional específica para cercá-lo. 
é o bastante para perturbar a superfície em diversos aspectos e tornar a linearidade e a separação entre presente e passado mera ilusão de ótica.

Ao se negar a buscar associações, contextos e ligações e ao fazer o espectador percorrer lentamente com ela aqueles territórios carregados simbolicamente, a imagem forma um palimpsesto, pois é na superfície do cotidiano que a memória ameaçada pela incerteza do novo mundo ainda resiste. Quando reivindicamos o modo político intersticial, próximos a José Marie Mondzain, percebemos a potência política de um terceiro que, junto com Chantal, vem projetar o imaginário do Holocausto quando a memória ainda sobrevive. E é a travessia perceptiva pelo Leste Europeu que evoca o imaginário como um inventário de imagens já vistas, porém jamais vistas10. Se Akerman parece recusar o historicismo, é que, como Benjamim, ela alcança um mecanismo em que a história escrita a contrapelo não pode fazer uso dos emblemas deixados pela história oficial, reificada nos museus, mas a partir da memória como lacuna e invenção que se institui na duração das cenas e no presente da gênese da imagem.

Roberta Oliveira Veiga é professora do Programa de Pós-Gradução em Comunicação pela UFMG. É doutora pelo mesmo programa e editora da revista Devires: Cinema e Humanidades; é integrante do comitê científico do forumdoc.bh (Festival de Cinema Etnográfico de Belo Horizonte) e pesquisadora do grupo Poéticas da Experiência (UFMG). Traduziu o livro Nothing Happens: Chantal Akerman's Hyperrealist Everyday, de Ivone Margulies.

roveigadevolta@gmail.com

\section{Referências}

AKERMAN, C. A propósito de D’est. In: Revista Devires: cinema e humanidades. Universidade Federal de Minas Gerais (FAFICH). v. 7, n.1, 2010.

ARAÚJO, M. Um experimento documental: D’Est (1993), de Chantal Akerman. Território Expandido. http://territorioexpandido.com.br/files/download/doleste.pdf. Acesso em 20/09/2018.

BLANCHOT, M. A fala cotidiana. In: A conversa infinita: A experiência limite. São Paulo: Escuta, 2007.

9 "O terceiro não ocupa o lugar do todo porque a imagem é um regime de deslocação, no sentido próprio da palavra. A imagem não tem lugar. Utopia e distopia, ela instaura a temporalidade histórica de uma circulação de lugares" (MODZAIN, 2011, p. 109).

10 Faço aqui um trocadilho com o título do filme de Andrea Tonacci, Já visto, jamais visto, de 2015, em referência ao esburacamento da memória que o cineasta faz ver no processo e no dispositivo de seu filme, montado que é com imagens de arquivo de sua carreira, de temporalidades diversas, que possuem uma ligação frágil entre elas (Cf. VEIGA, 2015). 
BENJAMIN, W. A imagem de Proust. In: Magia, técnica, arte e política. Obras escolhidas. São Paulo: Brasiliense, 1994.

N-Teoria do conhecimento, teoria do progresso. In: Passagens. Belo Horizonte: Editora UFMG, São Paulo: Imprensa Oficial do Estado de São Paulo, 2006. Paulo, 2007.

Passagens. Belo Horizonte: Editora UFMG; São Paulo: Imprensa Oficial do Estado de São

CASTELLO BRANCO, L. A traição de Penélope: uma leitura da escrita feminina na memória. Tese de doutorado. UFMG-FALE, maio de 1990.

COMOLLI, J-L. Ver e poder: a inocência perdida: cinema, televisão, ficção, documentário. Belo Horizonte: UFMG, 2008.

DIDI-HUBERMAN, G. Diante do Tempo: história da arte e anacronismo das imagens. Belo Horizonte: Ed. UFMG, 2015.

LEBOW, A. Memory once removed: indirect memory and transitive autobiography in Chantal Akerman's D'Est. In: Camera Obscura 52, Volume 18, Number 1. Duke University Press, 2003.

LÖWY. M. Walter Benjamin: aviso de incêndio - uma leitura das teses "Sobre o conceito de história". São Paulo: Boitempo, 2005.

MARGULIES, I. Nada acontece: o cotidiano hiper-realista de Chantal Akerman. Trad. Roberta Veiga e Marco Aurélio Sousa Alves. São Paulo: Edusp, 2016.

MONDZAIN. M. J. Nada tudo qualquer coisa ou a arte das imagens como poder de transformação. In: SILVA, R.; NAZARÉ, L. (org). A república por vir. Arte, Política e Pensamento para o século XXI. Lisboa: Fundação Calouste Gulbenkian, 2011.

VEIGA, R. Quantos enquadramentos cabem no enquadramento de uma janela? Devires: Cinema e Humanidades, FAFICH-UFMG, v.7, n.1, 2010.

O confinamento de Vanda: uma leitura do dispositivo. In: Doc On-line, n. 18, setembro de 2015a, www.doc.ubi.pt, p. 192-215.

. Já visto jamais visto: um filme de filmes ou o devir memória. In: Revista Crítica Cultural Critic, Palhoça, SC, v.10, n. 1, p. 87-96, jan./jun. 2015b.

YOUMANS, G. Ghosted Documentary: Chantal Akerman's Là-Bas. In: Millennium Film Journal; Spring 2009; 51, p. 70. 